\title{
Bölgesel Kümelenme Örneği Olarak Ahilik Teşkilatı
}

\author{
Ayşe Nurefşan YÜKSEL \\ Kırşehir Ahi Evran Üniversitesi \\ ayse.bali@ahievran.edu.tr \\ ORCID ID: 0000-0003-3107-9519 \\ Aykut GÖKSEL \\ Ankara Hacı Bayram Veli Üniversitesi \\ aykut.goksel@hbv.edu.tr \\ ORCID ID: 0000-0003-2780-8117
}

\begin{tabular}{lr} 
Araştırma Makalesi & DOI: $10.31592 /$ aeusbed.700672 \\
\hline Geliş Tarihi: 09.03.2020 & Revize Tarihi: 12.10.2020 \\
Atıf Bilgisi & \\
Yüksel, A. N. ve Göksel, A. (2020). Bölgesel kümelenme örneği olarak ahilik teşkilatı. Ahi Evran Üniversitesi \\
Sosyal Bilimler Enstitüsü Dergisi, 6(3), 794-812.
\end{tabular}

ÖZ

\begin{abstract}
Ahilik, XIII. yüzyılda Anadolu'da ortaya çıkmış ve yüzyıllarca varlığını sürdürmüş olan kültürel, eğitsel, dini, idari, askeri ve ekonomik bir teşkilattır. Ahilik teşkilatının ekonomik anlamda mesleki birliktelikler olarak teşkilatlandığı görülmektedir. Kümelenmeler ise birbiriyle bağlantılı olan işletmeler ve kurumların, belirli yerlerde, coğrafi olarak yoğunlaşmalarıdır. Bu yoğunlaşmalar, genellikle hammaddenin yoğun, pazarın büyük veya talebin çok olduğu durumlarda oluşmaktadır. Sayılan bu özellikler, ahilik teşkilatı meslek birliklerinin şehirlerdeki oluşumlarında da rol oynamaktadır. Ahilik teşkilatının mesleki birlikler olarak teşkilatlanmış olmakla, günümüz kümelenmeleriyle benzerlik gösterdiği düşünülmektedir. Bu çalışmanın amacı, bu benzerliği araştırmak, ahilik teşkilatının bir kümelenme örneği olarak nitelenmesinin mümkün olup olmadığını teorik çerçevede tespit etmeye çalışmaktır. Bu amaçla çalışmada, nitel veri toplama yöntemlerinden yazılı doküman incelemesinden faydalanılarak veriler toplanmıştır. Kümelenme kavramı özellikleri ele alınmış, bu kapsamda daha önceki toplumlarda oluşmuş olan ve kümelenme özellikleri gösteren ahilik teşkilatı incelenmiş, benzerlikler tespit edilmiş ve aynı zamanda günümüz toplumlarının oluşturmuş olduğu kümelenmelerle karşılaştırılmıştır. Çalışma boyunca devam eden karşılaştırmalı analizler neticesinde, ahilik teşkilatının, kümelenme özelliklerini taşıdığ 1 ve bölgesel bir kümelenme modeli olarak ele alınabileceği belirtilmiştir.
\end{abstract}

Anahtar Kelimeler: Ahilik, ahilik teşkilatı, kümelenme, yazılı doküman incelemesi.

\section{Ahi Organizations As a Regional Clustering Example}

\begin{abstract}
Ahi organizations (akhism), is a cultural, educational, religious, administrative, military and economic organizations that has emerged in Anatolia in the 13th century and maintained its exictence for centuries. On the economic framework it is seen that Ahi organizations has organized as professional association. Clusterings, on the other hand, are geographical concentrations of interconnected businesses and institutions. This concentrations generally consists in the conditions that the raw material is intensive, the market is large and demand is high. It is understood that these features also play a role in the formation of ahi organizations' professional associations' in cities. It is thought that the ahi organizations, being organized as professional associations, has similar characteristics to today's clusterings. The aim of this study is to investigate this similarity and try to determine whether it is possible to describe the ahi organizations as a clustering example in the theoretical framework. For this purpose, the data were collected by written document analysis, which is one of the qualitative data collection methods. The features of cluster concept are discussed. In this context, the organization of Akhism, which was formed in previous societies and has cluster characteristics, was examined, similarities were determined and at the same time compared with the clusters formed by today's societies. Therefore, in this article, it is examined in the light of the comparative analysis, that Akhism is a regional cluster example.
\end{abstract}

Keywords: Akhism, ahi organizations, clustering, written document analysis.

\section{Giriş}

Ahilik, XIII. yüzyılda Anadolu'da, dini ve toplumsal bir yapı olarak ortaya çıkmış olup; zaman içerisinde esnaf ve sanatkarlar teşkilatı halini almış ve XVIII. yüzyıla kadar varlığını sürdürmüş olan bir teşkilattır (Çağatay, 1989; Kazıcı, 1988). Her toplumsal teşkilatın, içinde oluştuğu toplumun 
belirli ihtiyaçlarını karşıladığı ve dönemin şartlarına göre şekil aldığı bir gerçeklik olup, ahilik teşkilatı da Selçuklu Dönemi Anadolusunda dönemin şartlarına göre çeşitli görevler üstlenmiştir (Güllülü, 1977). Buna göre ahilik teşkilatı, hem toplumsal, kültürel, eğitsel ve dini; hem idari, siyasi ve askeri; hem de ekonomik, sınai ve ticari faaliyetlerde bulunmuştur. Ancak, Osmanlı Devleti'nin merkezileşmesi ile birlikte, örf, adet, gelenek ve prensipleriyle tamamen esnafi temsil eden bir teşkilat olarak varlığını sürdürmüştür (Küçükdağ, 2016). Ahilik teşkilatı, Osmanlı Devleti üretim sisteminin temel kurumu olarak, devletin esnaf teşkilatı kimliğiyle yaşamış, aynı zamanda örgütlenme ve uzmanlaşma birimlerinin sayısı bakımından tarihteki diğer Ortadoğu toplumlarının benzer teşkilatlarına göre daha gelişkin bir hal almıştır (Ortaylı, 2010).

Ahilik teşkilatının kurulduğu dönemde şehir üretim sistemleri, şehrin ve etrafındaki köylü ve göçebelerin ihtiyaçlarını karşılamak amacıyla çalışan sistemler olmuştur. Şehre özgü hammaddelerin o şehirde veya yakın çevresinde oluşu, belirli tarz işçilik tekniğinin gelenek halinde bir şehirde toplanması gibi sebepler; şehir üretim sistemlerinin gelişimini etkilemiştir. Geleneksel şehirlerin merkezlerinde esnaf teşkilatlarının binası bulunduğu gibi Osmanlı şehirlerinin merkezlerinde de ahilik teşkilatının binası olarak bedestenler yer almıştır. Bedestenler şehrin merkezindeki büyük meydan üzerinde yer almış, etrafında ise diğer esnaf ve sanatkarların çarşıları kurulmuştur (Köprülü, 2015; Ortayl1, 2010).

Ahilik teşkilatının bazı özellikleri ile kümelenmelere örnek teşkil ettiği görülmektedir. Nitekim kümelenmeler, birbiriyle bağlantılı olan işletmeler ve kurumların belirli yerlerde coğrafik olarak yoğunlaşmalarıdır (Porter, 1998b). Bu yoğunlaşmalar ise genellikle hammaddenin yoğun bulunduğu, pazarın büyük olduğu veya talebin çok olduğu durumlarda oluşmaktadır (Mercan, Halıcı ve Baltac1, 2004). Sayılan bu özelliklerin, ahilik teşkilatı meslek birliklerinin şehirlerdeki oluşumlarında da rol oynadığı anlaşılmaktadır.

Literatür incelendiğinde, Kala'nın (2012), kitabının ilk bölümünde ahilik teşkilatı üretim modelini, "Ahi Evren'in Ahi Kümelenme Modeli" olarak adlandırdığı, ahi kümelenme modelini çeşitli yönlerden ele aldığ1; Eraslan ve Güngören'in (2013), endüstriyel kümelenmelerin iktisadi tarihi ve gelişim sürecini inceledikleri çalışmalarında, "Ahilik Tipi Sosyo-Ekonomik Teşkilatlanma ve Üretim Modeli” yapılarının, günümüz kümelenme yapıları ile benzerlik arz ettiğini, hatta bu yapıların ilk endüstriyel kümelenme ve gelişme modellerinin kökenlerini oluşturduğunu belirttikleri görülmüştür. Şenyurt (2014) ise Kala'nın (2012) adlandırdığı şekliyle “Ahi Evren'in Ahi Kümelenme Modeli” nin Osmanlı Tersaneleri'nin gelişimindeki rolünü incelediği bir çalışma ortaya koymuştur. Tüm bu çalışmalarda ahilik teşkilatının kümelenme modeli olarak ele alındığı, ancak konuya teorik çerçevede bir açıklama getirilmediği anlaşılmaktadır. Dolayısıyla bu makalede, ahilik teşkilatının bölgesel bir kümelenme örneği olduğu, yazılı doküman incelemesi yöntemiyle toplanan veriler 1şığında incelenmiştir. Ahilik teşkilatı ve kümelenmelerle ilgili toplanan veriler karşılaştırma olanağı sunduğundan, ahilik teşkilatının içerdiği kümelenme özellikleri; kümelenmelerin belirli özellikleri ve Porter'ın belirlediği kümelenme boyutları açısından ele alınarak karşılaştırmalı bir analiz yapılmıştır. $\mathrm{Bu}$ karşılaştırmalar, sosyolojik bir oluşum olan ahilik teşkilatının teorik çerçevede incelenmiş olmasına katkı sağlamıştır.

\section{Ahilik Teşkilatı}

Ahilik teşkilatı, XIII. yüzyılda Anadolu'da, sosyal, kültürel, siyasi ve ticari şartların etkisi ile ve Ahi Evran'ın rehberliğinde kurulmuştur. Ahi Evran, ahilik anlayışı ve bu anlayışın ilişkili olduğu fütüvvet anlayışının Anadolu'da yayılmasını sağlamıştır. Hoy kasabasında doğan ve muhtemelen çocukluğu memleketinde geçen Ahi Evran ilk tasavvuf derslerini Horasan ve Maveraünnehr'deki dervişlerden almıştır. Bir süre sonra Abbasi halifesi Nasır-lidinillah tarafından Anadolu'ya gönderilmiş, Kayseri'ye yerleşerek debbağlık imalathanesi kurmuş, mesleği olan debbağlığı sürdürürken; diğer taraftan şeyhi Kirmanı ile birlikte ahiliği yaymaya başlamıştır (Celil, 2011). Bu şekilde, Moğol saldırısı yüzünden Anadolu'ya göçen Türk esnaf, sanatkar ve tüccarları geniş bir teşkilat halinde (ahilik teşkilatı) ve fütüvvet teşkilatının kurallarını içeren fütüvvetname adı verilen tüzükler çerçevesinde birleştirmiştir (Çağatay, 1983; Akt. Gülerman ve Taştekil, 1993). Franz 
Taeschner, ahiliğin, fütüvvetin "sosyal anlamıyla" birleşerek, Ortaçağ Türk Anadolu'sunun sosyal ve kültürel şartlarının etkisi ile Türklere özgü ve diğer İslam ülkelerinde görülmeyen bir esnaf teşkilatı haline gelmiş olabileceğini savunmuştur (Aslan, 2014; Odabaş1, 2008). Köprülü (2015) de büyük merkezlerdeki esnaf korporasyonları - ki bunlar ahi teşkilatlarıdır- ile fütüvvet teşkilatının birbirinin içine girerek her iki zümreye de birden mensup olan kişilere denk gelinebildiğinden, aynı zamanda fütüvvet kelimesinin bir "ahlaki prensip" olarak esnaf korporasyonları arasında mevcut olduğundan bahsetmiştir. Dolayısıyla rahatlıkla savunabileceğimiz gerçek, Anadolu'nun XIII. yüzyıldaki şartları, çeşitli toplulukların ve bazı sosyolojik grupların oluşmasını gerekli kılmıştır. Ahilik teşkilatı da bu gruplardan biri olarak oluşmuştur.

Ahi Evran'ın rehberliği sayesinde Anadolu'ya yerleşen göçmenler de, şehirlere yerleştikten kısa bir süre sonra, daha önce çalıştıkları iş kollarına uygun olarak imalathane ve ticarethanelerini kurmuşlardır. Sanatlarında başarılı olabilmeleri ve yerli pazardan pay alabilmeleri için aralarında dayanışma içinde olmaları gerekmiş̧ir. Dolayısıyla, Fütüvvet teşkilatının moral ve etik kurallarının benimsenmesi; aynı meslekten olan kimselerin bir çatı altında toplanmasını kolaylaştırmıştır (Doğru, 1991).

\section{Ahilik Teşkilatının Ekonomik Faaliyetleri ve Örgütsel Yapısı}

Esnaf teşkilatı genel olarak, hammaddeyi etraftan toplayan, bunları işleyecek araç ve personeli barındıran ve ürettiğini satan bir sistemdir. Osmanlı Devleti'nin esnaf teşkilatı olan ahilik teşkilatı da Osmanlı üretim sisteminin temel kurumu olarak yaşamıştır (Ortaylı, 2010).

Osmanlı şehirlerinin merkezlerinde ahilik teşkilatının binası olarak bedestenler yer almıştır. Bedestenler şehrin merkezindeki büyük meydan üzerinde yer almış ve meydan etrafındaki sokaklarda ise diğer esnaf ve sanatkârların çarşıları kurulmuştur. Bu sokaklar, bezzazlar, saraçlar, kavaflar, sahaflar, yemeniciler, bakırcılar gibi isimler almıştır (Ortayl1, 2010). Bu durum İstanbul Kapalıçarşı Haritası'nda görülmektedir (Harita 1).

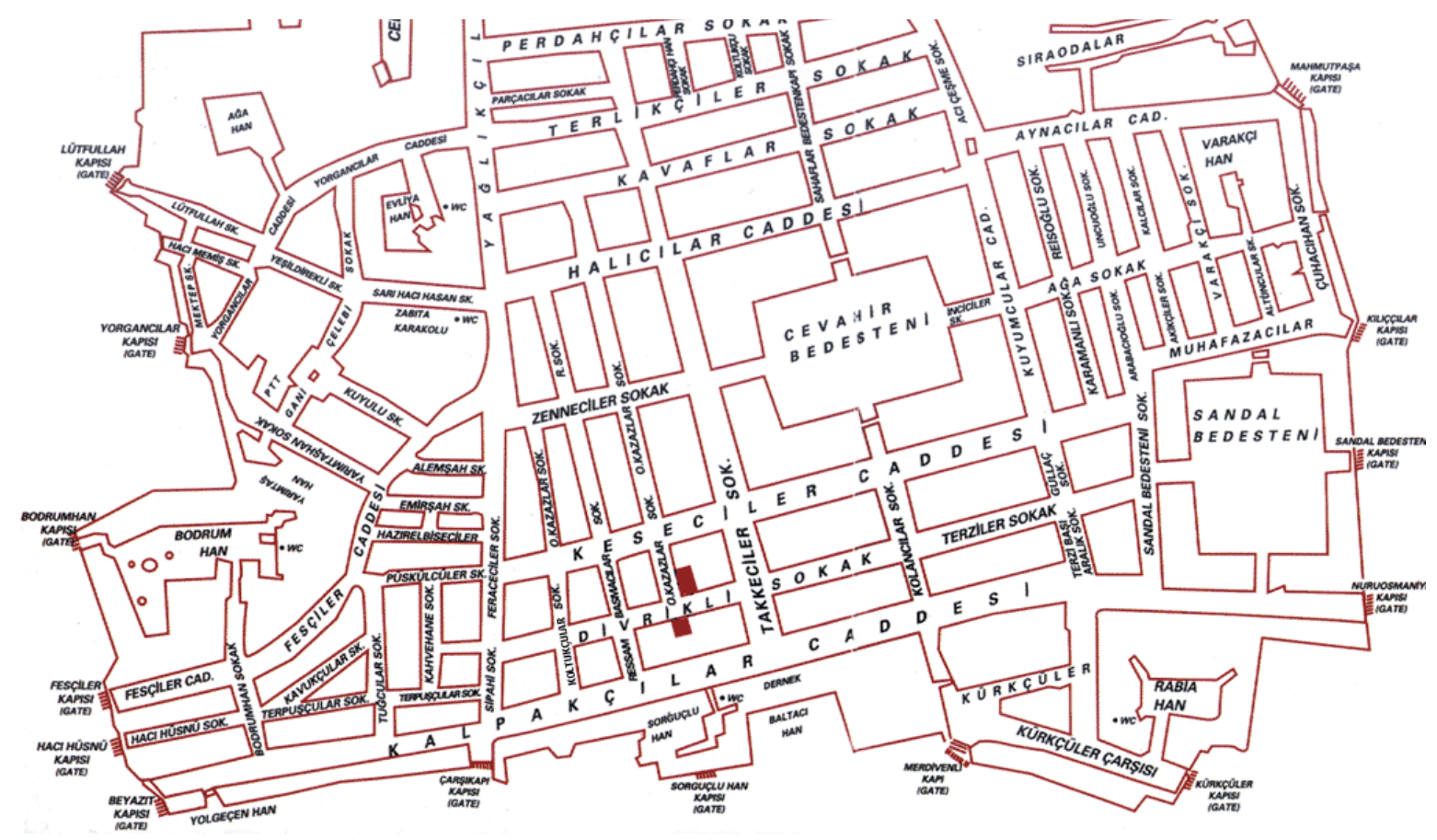

Harita 1. İstanbul Kapalıçarşı Haritası 
$\mathrm{Bu}$ çarşılar kapalı veya açık olabildiği gibi, şehirlerin genişliklerine, bazı sanatların orada daha ilerlemiş ve merkezileşmiş bir şekilde bulunmasına göre büyüklükleri ve sayıları değişmiştir (Köprülü, 2015).

Kusursuz bir hiyerarşi ile işleyen ahilik teşkilatı, bir sorun ortaya çıktığında kendi içinde çözmüş, devlet ile esnaf arasındaki ilişkileri düzenlemiştir. Ücretlerin, ürün çeşitlerinin ve fiyatlarının belirlenmesi; belirli miktar ve kalitede üretimin sağlanması gibi düzenlemeler ahilik teşkilatının işleri arasında yer almıştır (Köprülü, 2015). Taeschner da, ahilik teşkilatının ürün ve kalite kontrolü ile fiyat tespiti görevlerinin asli görevleri olduğunu belirtmiştir (Odabaşı, 2008).

Her ahi, belirli kalite ve miktarda hammadde kullanmış, belirli üretim tekniklerine bağlı kalarak ürün üretmiş ve imal ettiği eşyayı belirli fiyata satmıştır. Bu hususlarda değişik usullere başvuranlar cezalandırılmıştır. Ahilik teşkilatında, esnaf adabının yitirilmesine sebep olacak şekilde üretimin geliştirilmesi ve fazla kar sağlama amaçlarına itibar edilmemiştir (Şimşek, 2002).

Ahilik teşkilatında esas ilişki usta-çırak iliş̧isidir. Etkili eğitim ve denetimin sağlanması bu ilişki sayesinde kolaylaşmıştır. Çıraklar genç yaşta işe başlayıp ustalarının gözetimi ve disiplini altında işlerini öğrenmişlerdir (Ortaylı, 2010). Çıraklıktan ustalığa geçmek ve böylece dükkân açabilmek için şart, o iş üzerine uzun süre çalışıp, işin tüm inceliklerine hâkim olmak ve ustaların önünde önemli bir imtihanı vermek olarak belirlenmiştir (Akdağ, 2014). Bu şekilde belli bir süre bir kademede kalarak pişirilen çırakların aynı zamanda baba evlat ilişkisi gibi candan bağlarla bağlanmasıyla güçlü bir iş ahlakı oluşmuştur. Bu iş ahlakının gerektirdiği bir şekilde hem esnaf ve sanatkârların hem de üretici ve tüketicilerin arasındaki ilişkiler rekabet ve kavgaya yol açmayacak şekilde düzenlenmiştir.

Ahi Evran'ın Anadolu'daki bütün sanatlara pir kabul edilmesi sonucunda ahilik teşkilatı merkezi bir sistemle yürütülmeye başlanmış, Ahi Evran Zaviyesi bu teşkilatın genel merkezi haline gelmiştir. Anadolu'nun her yerinde Ahi Baba atamaları ve terfi törenleri zaviyedeki ahi şeyhlerinin onayıyla yapılmış, bu zaviyenin şeyhleri her yıl belirli zamanlarda Anadolu'yu dolaşarak zaviyeleri denetlemiş̧lerdir (Güllülü, 1977).

Ahilikte mesleki dereceler olarak da adlandırabileceğimiz dereceler, yamaklık, çıraklık, kalfalık ve ustalıktır. Yamak, çırak, kalfa ve ustalar (üstad) aynı zamanda ahilik teşkilatının üyesidirler. Ahilik teşkilatında üyeliğe kabul işlemleri iki aşamada gerçekleşmektedir. İlk aşamada teşkilata girmeyi isteyen kişi, müracaatını yapmakta, bu kişiye talip denmektedir. İkinci aşamada talipte aranılan özellikler titizlikle incelenmekte; bazen aylarca süren incelemeler ile onların ahi olmalarını engelleyecek bir durumun olup olmadığı araştırılmaktadır (Gülerman ve Taştekil, 1993).

Ahilik teşkilatında, meslek hayatının ilk kademesi yamaklıktır. İki yıl parasız ve sürekli yamaklık edenler, velisinin, ustasının ve kalfalarının katılacağı bir törenle çıraklığa yükselmektedirler. Çıraklar, çıraklık süresi olan 1001 günü (üç yıl) tamamlayarak, kalfalığa yükselebilecek bilgiye sahip olduklarında; usta ve kalfalarının yardımı ile bir sınavdan geçmekte ve kalfalığa yükselmektedirler (Turan, 1996). Kalfalık dönemi de tüm meslek ve sanat kolları için yaklaşık üç yıl olarak belirlenmiştir (Şimşek, 2002). Üç yılın sonunda pişen kalfalar, bağımsız iş yeri kurup çalıştırma yeterliliğini ispatlayınca ustalığa yükselmeye hak kazanmaktadırlar. Bu durumun şedd kuşatılarak herkese duyurulması gerekmektedir (Soykut, 1980).

Ahilik teşkilatında mesleki konularla ilgili belirli kurallar konulmuştur. Bu kurallar teşkilat içerisinde düzeni sağlamış, haksız rekabeti önlemiştir. Dolayısıyla, denetim mekanizmasıyla, kurallara uymayanlar teşkilat yönetimi tarafından denetlenmiş; yaptırım yönü kuvvetli cezalar verilerek düzen sağlanmaya çalışılmıştır. Ahilik teşkilatında ana kural, bir sanat ya da meslek sahibi olmak şeklinde belirlenmiştir. Fütüvvetnamelerde bu konuda şöyle denilmiştir: "Ahilere helal para kazanmak gerektir ve hem vaciptir ve hem sünnettir. Her kimin ki meslek ya da sanatı yoksa ona fütüvvet değmez. Ahinin on sekiz dirhem gümüş sermayesi ve mutlaka bir işi olmalı; işsiz olmamalı" (Çağatay, 1988). 
Mesleki kurallar ve bu kurallara uymayanlara uygulanacak cezaların örnekleri ahilik teşkilatının tüzükleri olan şecerenameler kaynak alınarak, şu şekilde verilebilir:

- Hammadde alımı genellikle esnaf başkanları ve esnaf kurulu tarafından tek elden yapılmış ve adil bir biçimde ustalara paylaştırılmıştır. Esnaf başkanından izinsiz hammadde alan olursa cezalandırılacağı belirtilmiştir. Ahilik teşkilatına üye de olsa hatta usta dahi olsa, hammaddeyi izinsiz alanların cezalandırılacağı belirtilmiştir (Köksal, Kurtoğlu, Karaköse ve Şenödeyici, 2008).

- Ahilik teşkilatında, hammadde alımı ve sonrasında dağıtımı için hisseler belirlenmiştir. Ustaların ve kalfaların kıdemlerine göre, zaviyede çalışanların ise görev seviyelerine göre belirlenen bu hisselere göre hammadde paylaşımı yapılmış, şecerenamedeki paylaşıma güvenmeyenlere beddua edilerek, teşkilattan kovulacakları açıklanmıştır (Köksal vd., 2008).

- $\quad$ Bir de ahilik teşkilatında iki sanatın bir yerde olamayacağı kuralı bulunmuştur. Yani bir kişinin sadece bir sanatla, diğer bir deyişle tek bir meslekle uğraşarak uzmanlaşması kuralı konulmuş ve bu kurala uymayanların da teşkilattan kovulması gerektiği belirtilmiştir: "Hazret-i Abbas buyurdu ki kasap olan tabak; dikici olan tacir olmaz. İki sanat bir yerde olmaz. Eğer olursa muradına eremez. Büyük sözü dinlemeyen töresizdir, ocaktan ihraç edin" (Köksal vd., 2008).

- $\quad$ Üretilen eşyanın satış fiyatının tespiti de ahilik teşkilatı tarafından yapılmıştır. Üretilen eşyayı tespit edilen fiyattan daha düşük ya da daha yüksek fiyata satmaya kalkışmak teşkilat yasalarına aykırı bulunup, yasaklanmıştır (Güllülü, 1977).

\title{
Kümelenme
}

Belirli bir faaliyet alanında uzmanlaşmış işletmelerin, değer zinciri içerisinde mevcut olan diğer işletmelerle birlikte oluşturduğu coğrafi yoğunlaşmaya "yığın" denilmekte; bu yığınlar içerisinden, rekabet avantajı kazanmak amacıyla bilinçli bir işbirliği kurabilen işletme ve kurumlar küme olarak adlandırılmaktadır. Bu coğrafi yoğunlaşmaların küme olarak adlandırılabilmesi için işletmeler ve ilişkili oldukları kurumlar arasında kurulan işbirliğinin bilinçli ve sürekli olması gerekmektedir (Türkiye Cumhuriyeti Ekonomi Bakanlığı, t.y.). Dolayısıyla kümelenmenin klasik tanımını "aynı bölgede, aynı iş kolunda, aynı değer zincirinde faaliyet gösteren, birbirleriyle işbirliğinde bulunan ve aynı zamanda birbirine rakip olan işletmelerin ve onları destekleyici kurumların (üniversiteler, kamu kuruluşların, mesleki dernekler vb.) bir araya geldikleri örgütlenme modeli" şeklinde yapmak mümkündür (İmer, 2015).

Kümelenme kavramının literatürde kullanılmasına öncülük eden Porter ise kümeleri şu şekilde tanımlamaktadır:

\begin{abstract}
"Kümeler birbiriyle bağlantılı olan işletmeler ve kurumların belirli yerlerde coğrafik olarak yoğunlaşmalarıdır. Kümeler, rekabet açısından önemli olan birbiriyle bağlantılı endüstrilerin; bileşen, makine ve hizmet sağlayan uzmanlaşmış tedarikçilerin ve uzmanlaşmış altyapı sağlayıcılarının tamamını kapsar. Kümeler genellikle dikey olarak tedarik kanallarına ve müşterilere; yatay olarak ise tamamlayıcı ürünler üretenlere ve endüstrideki yetenek, teknoloji ile girdi kullanımı açısından ilişkili olunan işletmelere kadar uzanır. Son olarak kümelerin çoğu; kamu kurumları ve üniversiteler, standardizasyon kurumları, düşünce kuruluşları ve mesleki eğitim kurumları gibi uzmanlaşmış eğitim-öğretim imkânları, araştırma olanakları ve teknik destek sağlayan diğer kurumları da kapsar" (Porter, 1998b, s.78).
\end{abstract}

Morosini (2004) ise endüstriyel kümelerin sosyal olarak yapılanmış varlıklar olduğuna vurgu yapan şu tanımı yapmaktadır:

"Endüstriyel bir küme, belirli bir coğrafik alanda birbirleri ile yakın mesafeye yerleşmiş olan sosyal grup üyeleri ve ekonomik birimlerden oluşan bir topluluk tarafından temsil edilen sosyoekonomik bir varlıktır. Endüstriyel küme içindeki sosyal grup üyelerinin ve ekonomik birimlerin önemli bir bölümü, nitelikli ve kaliteli ürünler üreterek pazara hizmet etmek için, ekonomik olarak 
ilişkili faaliyetlerde birlikte çalışmakta; ürün, teknoloji ve bilgi paylaşımı yapmaktadır" (Morosini, 2004, s.307).

Yüksek seviyedeki sosyal sermaye, kümelenmeyi oluşturan aktörler arasındaki dayanışmayı tahsis ederek, grup kimliğini kazandırmakta "biz" duygusunu ortaya çıkarmaktadır (Aziz ve Norhashim, 2008). Kümelenme ile ilgili yapılan araștırma ve çalıșmalarda, ișletmelerin kümelenme faaliyeti adı altında bir araya gelme nedenleri arasında, bölgesel ya da küresel rekabet avantajı sağlamak, ortak faaliyet alanı oluşturmak, etkin bir tedarik zinciri oluşturmak, yenilik ve değişimi yakalamak gibi nedenlerle birlikte; coğrafi yakınlık nedeniyle sinerji oluşturmak da sayılmaktadır (Akdağ, Mete ve Emhan, 2014). Kümelerin merkez ve tamamlayıcı endüstrileri ile bilgi sağlayan kurumları arasında sinerjik bir ilişki olmalıdır. Eğitim kurumları, kamu kurumları, yerel yönetimler, odalar ve diğer işbirliği kurumları; özel sektörü desteklemeli, böylece bölge ekonomisinin gelişmesini, yeni istihdam alanları açılmasını ve bir bütün olarak bölgesel kalkınmanın gerçekleşmesini sağlamalıdır (Türkiye Cumhuriyeti Ekonomi Bakanlığı, t.y.).

\section{Porter'ın Kümelenme Yaklaşımı}

Kümelenme kavramı, Porter'ın 1990 yılında “Ulusların Rekabetçi Avantajı” üzerine yazdığı kitabının yayımlanmasından itibaren, güncel akademik literatürün yoğun şekilde tartışılan konularından birisi ve dünya çapında ulusal endüstriyel politikaların odak noktası haline gelmiştir.

Porter, rekabetçi avantaj kazanabilecek olan işletmelerin coğrafi olarak yoğunlaşma sebeplerini, birbiriyle ilişkili dört ana bileşene dayalı, "Elmas Modeli" olarak tanımladığı kavramsal bir model ile açıklamaya çalışmaktadır (İmer, 2015). Porter'ın Elmas Modeli'nde, bir kümelenmenin rekabetçi gücünü belirleyen elemanlar, birbirleriyle karşılıklı etkileşimde olan dört temel ve buna ilave iki destekleyici unsurdan oluşmaktadır (Yıldız ve Alp, 2014). Temel unsurlar, faktör koşulları, talep koşulları, ilgili ve destekleyici endüstrilerin gücü ile firma yapısı, stratejisi ve rekabet şartlarıdır. Destekleyici iki unsur ise, şans faktörü ve hükümetin rolüdür. Destekleyici bu iki unsur, temel unsurları etkilemektedir, fakat tek başlarına belirleyici özellikleri bulunmamaktadır.

- $\quad$ Faktör Koşulları: Faktör koşulları ülkelerin, endüstride rekabet etmeleri için gerekli olan, vasıfsız ve vasıflı iş gücü, doğal kaynaklar, iklim koşulları, sermaye kaynakları veya alt yapı gibi üretim faktörlerindeki durumlarını ele almaktadır (Porter, 1990a). Porter, belirli bir bölgede bulunan faktör koşullarının miktarı ve maliyetinin de o bölge için önem arz ettiğini belirtmektedir (Porter, 2000). Örneğin, Pensilvanya'daki kümelenmeler belirli bir bölgede bulunan fiziksel kaynağa bağlı olarak oluşmuş kümelerdir. $\mathrm{O}$ bölgede çokça sayıda kömür sahaları ve çelik kaynakları bulunmaktadır (John ve Pouder, 2006). Porter (1990b), faktör koşullarını beş geniş kategoride gruplayarak ele almaktadır: İnsan kaynakları, fiziksel altyapı (doğal kaynaklar), bilgi kaynakları, sermaye kaynakları, altyapı imkanları.

- $\quad$ Talep Koşulları: Bir endüstrideki ürün ve hizmetlere yönelen yerel talep koşulları, endüstrideki kümelenmelerin rekabetçi gücünü belirleyen önemli unsurlardan ikincisidir. Porter, yerel talep koşullarının neredeyse her endüstride bazı etkileri olduğunu belirlemiştir (Porter, 1990b).

- Ilgili ve Destekleyici Endüstriler: İlgili ve destekleyici endüstriler, kümelenme ile ilişkili endüstrilerin varlığı kadar, malzeme, tamamlayıcı parça, makine ve hizmet tedarikçilerinin yereldeki çokluğunu ya da yokluğunu da ifade etmektedir (Porter, 1998a). İlgili endüstriler ile çalışma alanları ilişkili olup rekabetçi olan endüstriler; destekleyici endüstriler ile ise özellikle tedarikçi konumundaki firmalar açıklanmaya çalışılmaktadır.

- $\quad$ Firma Yapısı, Stratejisi ve Rekabet: İşletmelerin nasıl oluşturulup organize edileceği, yönetileceği, stratejileri ve aynı zamanda ülke içindeki rekabetin nasıl olacağı konularındaki eğilimler, ülkeden ülkeye değişiklik göstermektedir. Evrensel olarak kabul görmüş tek bir yönetim şekli bulunmamaktadır (Porter, 1990a). 
- $\quad$ Sans Faktörü: Bir ülkenin veya endüstrinin rekabet koșullarını etkileyen, rastlantısal olarak gerçekleşen ve firmaların müdahale edemediği olaylar şans faktörünü oluşturmaktadır. Şans faktörü, bir endüstrinin rekabet koşullarında ani değişikliklere sebep olurken, burada ülkenin veya endüstrilerin özellikleri, şans faktöründen nasıl yararlanacakları noktasında önemli rol oynamaktadır (Porter, 1990b).

- $\quad$ Hükümet Faktörü: Hükümetin, elmas modelindeki temel unsurların her birini olumlu ya da olumsuz bir şekilde etkileyebilme potansiyeli bulunmaktadır (Porter, 1990b). Ancak hükümetin asıl amacı, bir katalizör görevi üstlenerek, işletmeleri, amaçlarını gerçekleştirerek daha büyük amaçlara yönelme ve rekabetçi performans konusunda iyi bir noktaya ulaşmaları yönünde teşvik etmektir (Porter, 1990a).

\section{Yöntem}

Bu çalışmada, nitel araştırma yöntemi kullanılmış, nitel veri toplama yöntemlerinden yazılı doküman incelemesinden faydalanılarak veriler toplanmıştır. Kümelenme kavramı özellikleri ele alınmış, bu kapsamda daha önceki toplumlarda oluşmuş olan ve kümelenme özellikleri gösteren ahilik teşkilatı incelenmiş, benzerlikler tespit edilmiş ve aynı zamanda günümüz toplumlarının oluşturmuş olduğu kümelenmelerle karşılaştırılmıştır. Böylece sosyolojik bir oluşum olan ahilik teşkilatı, teorik çerçevede incelenmeye çalışılmıştır.

Ahilik teşkilatının içerdiği kümelenme özellikleri öncelikle Porter'ın belirlediği kümelenme boyutları açısından ele alınmış ve bir başlık altında incelenmiştir. Daha sonra kümelenme kavramının tanımı ele alınarak bu tanımda bahsi geçen özellikler ahilik teşkilatında aranmış ve ayrı bir başlık altında incelenmiştir. Böylece karşılaştırmalı bir analiz yapılmıştır. Örneklerin bir arada verildiği tabloda da görüleceği gibi hem geçmişte hem günümüzde oluşmuş olan kümelenmelerin benzer özellikler göstermesi bu çalışmada izlenen yolun doğruluğunu göstermiştir.

\section{Bulgular}

\section{Ahilik Teșkilatında Kümelenme Özellikleri}

Ahi Evran, geliştirdiği üretim modelinde, nüfus artışı ve şehirleşmeyle artan ihtiyaçları karşılamak amacıyla, küçük ölçekli birimlerin verimsiz ve yetersiz üretim faaliyetinin terkedilip, meslek grupları oluşturularak birlikler halinde örgütlenme şeklinde bir yapı kurmuştur. Ahi Evran bu model ile sanayi, tarım ve ticaret alanlarındaki üretim ilişkilerinin yeniden düzenlenmesini sağlamıştır (Kala, 2012).

Ahi Evran'ın genel olarak insanların ihtiyaçlarının karşılanması ve bunun meslek grupları oluşturularak yapılmasındaki düşünceleri Letaif-i Hikmet kitabından alıntılandığı şekliyle şu şekildedir:

\footnotetext{
"Allah insanı medeni tabiatlı yaratmıştır. Bunun manası şudur. Allah insanları yemek, içmek, giymek, evlenmek, mesken edinmek gibi çok şeylere muhtaç olarak yaratmıştır. Hiç kimse kendi başına bu ihtiyaçları karşılayamaz. Bu yüzden demircilik, marangozluk, gibi çeşitli meslekleri yürütmek için çok insan gerekli olduğu gibi, demircilik ve marangozluk da bir takım alet ve edevatla yapılabileceği için bu alet ve edevatı tedarik için de çok sayıda insana ihtiyaç vardır. Böylece insanın ihtiyaç duyacağı bütün sanat kollarının yaşatılması gerekir... Toplum, çeşitli sanat kollarını yürüten insanlara muhtaç olduğuna göre, bu sanatların her birini yürüten çok sayıda insanların belli bir yere toplanmaları ve her biri kendi sanatıyla meşgul olmaları gerekir ki, toplumun bütün ihtiyaçları görülmüş olsun" (Bayram, 1991, ss.137-152).
}

Aslında genel olarak medeni bir İslam toplumunda şehir merkezlerinin yapısı da insanların belirli yerlerde toplanmalarını sağlayacak şekilde düzenlenmiştir. Şehir merkezleri, merkezde cami olmak üzere çevresinde okul (medrese), zaviyeler ve çarşılar şeklinde oluşturulmakta ve şehir yeni 
gelenler ile bu merkez etrafinda büyümekte ya da bilinçli olarak büyütülmektedir. Ayrıca darüşşifa (hastane), çeşme, sebil, kervansaray (otel) ve mezarlık gibi yapılar da bu merkez etrafında inşa edilerek toplumun ihtiyaçları bu şekilde giderilmektedir (Bulut, 2014). İbn Batuta'nın seyahatnamesinde anlatılan şehir yapıları da bu görüşü desteklemektedir. Örneğin, İbn Batuta Antalya'yı anlatırken, Hristiyan tüccarların Mina adıyla tanınan mahallede oturduklarından, mahallenin çevresinde sur bulunduğundan; eski halk olan Rumların da diğerlerinden ayrı bir şekilde başka bir mahallede ikamet ettiklerinden; bey ile devlet adamları ve diğer hizmetlilerin de etrafı sur ile çevrilmiş diğer mahallelerden ayrılmış bir kalede oturduklarından bahsetmiştir. Müslüman halk ise asıl beldeye yani şehrin merkezine yerleştirilmişlerdir. Bu merkezde bir cami, medrese ve çok sayıda hamam ve güzel bir şekilde düzenlenmiş çarşılar bulunduğunu aktarmıştır (Şeker, 2001). Dolayısıyla bir bütün olarak düşünüldüğünde, Anadolu şehirlerinde toplumların yerleşim biçimlerinin de ayrıca kümelenme modelinin gelişimini desteklediği anlaşılmaktadır.

Ahi Evran'ın üretim modeli, ilk olarak Kayseri'de uygulamaya konulmuş ve böylece bu şehirde sanayi devrimi başlamıştır. Önce Selçuklu başkenti Konya ve Kayseri-Kırşehir'i içine alan bölgede sanayi devrimi başlamış, daha sonra çevreye yayılmıştır (Kala, 2012). Birçok kaynakta Ahi Evran'ın Anadolu'da kent ve kasabaları dolaşarak ahilik teşkilatını kurduğu belirtilmektedir (Doğru, 1991). Hatta ahilik teşkilatının kaynaklarından olan şecerenamelerde de bu konu çeşitli şekillerde anlatılmaktadır: "Sultan Ahi Evran Şeyh Mahmud bütün İslam ülkelerinde bulunan tabakhane ve ocakları diriltip bayındır hale getirdi. Etraftaki bütün ülkelere halifeler gönderip oraların da ocaklarını ihya ettiler. Zaviyeler ve binalar kurdular" (Köksal vd., 2008). Ancak özellikle Mikail Bayram'ın detaylı araştırmaları ve açıklamaları Ahi Evran'ın öncelikle Kayseri'ye yerleşerek ahilik teşkilatını orada kurduğunu, o dönemin büyük şehirlerine de hızla yayıldığını ve daha sonra şartlar gereği köylere yayıldığını göstermektedir. Kayseri'nin Anadolu Selçukluları Devleti'ne bir süre baş şehirlik yapmış olması, Selçuklular idaresinde bulunduğu dönemlerde Anadolu'nun en önemli ilim, sanat ve ticaret merkezi durumunda olmasını sağlamıştır. Aynı zamanda Anadolu'daki yollar dikkate alındığında, yine Kayseri'nin her açıdan önemli bir mevkide bulunduğu anlaşılmaktadır. Doğudan batıya, kuzeyden güneye uzanan yollar Kayseri’den geçmektedir (Bayram, 1991).

Ahi Evran genel olarak ilk kez, farklı meslek birlikleri oluşturularak bölge ihtiyacının karşılanmasını, bu meslek birlikleri arasındaki ilişkilerin düzenlenmesi ile kalite ve verimliliğin yükseltilmesini ve aynı faaliyet kolunda bulunan meslek birliklerinin bir arada kümelenmesi ile bölgesel rekabet avantajı kazanılmasını sağlayacak bir üretim modeli kurmuştur. Aynı zamanda devletin böyle bir üretim modeline dayalı hukuki bir sistem geliştirebileceğini de belirtmiştir. Bunu şu sözlerle ifade etmektedir:

\begin{abstract}
"İnsanlar gruplaştığı zaman, bu durum gruplar arasında düşmanlık ve çatışmalara sebep olur. Çünkü her bir grup kendi ihtiyacını talep eder. Birinin elinde olan şeye bir başkasının ihtiyacı olabilir. Ve herkes kendi talebine göre, elinde olan da olan şeye karşsllkk ister. Bu talepler karşılanabilir. Bazen de buna imkan olmaz. Bu yüzden insanlar arasında bir kanun olması gerekir ki bu kanun insanların çatışmalarını önlesin... Aralarında bir çatışma çıktığı zaman bu kanuna başvurulup çatışma ortadan kalksın” (Kala, 2012, ss.19-21).
\end{abstract}

Bu da Ahi Evran'ın üretim modeli ile Porter'ın Elmas Modeli arasındaki uyumu açıkça gözler önüne sermektedir. Çünkü Ahi Evran, Elmas Modeli'nin destekleyici unsurlarından olan hükümet faktörünü dahi öngörmüş, gerektiği noktalarda hükümete başvurmuştur.

Yine ahilik teşkilatı, Elmas Modeli'nin unsurları üzerinden incelenecek olduğunda, faktör koşullarının da göz önüne alındığı; doğal kaynakların olduğu yerlerde o doğal kaynağı işleyerek değerlendirecek mesleki birliklerin kurulduğu, alt yapının hali hazırda bulunduğu yerlerde mesleki birliklerin yoğunlaştı̆̆ görülmektedir. $\mathrm{Bu}$ durum İbn Batuta seyahatnamesinden kolaylıkla anlaşılmaktadır. Örneğin, Ladik'te (Denizli), pamuktan altın işlemeli ve şehrin adıyla anılan bir kumaş üretildiğinden, Konya'da Kamerüddin adı verilen kayısının Mısır ve Şam ülkelerine ihraç edildiğinden, Aksaray'da koyun yününden dokunan halılarının bir benzerinin olmadığından 
bahsetmiştir. Yine Gümüşhane'de gümüş madenleri olduğu, Erzincan'da bakır madeni olduğu, böylece orada şamdan ve benzeri bakır kapların üretildiği anlaşılmaktadır (Şeker, 2001).

Ahi Evran sadece yeterli üretimi sağlamanın ekonomiyi geliştireceğini düşünmemiştir. Yapılan üretimle toplumun ihtiyaçlarını karşılamayı da hedeflemiştir. Dolayısıyla Ahi Evran'a göre ekonomik anlamda gelişmişlik, üretim ile tüketim ilişkilerinin düzenlenip ihtiyaçların karşılanarak toplum refahının arttıılmasıdır. İnsan ihtiyaçlarının karşılanmasını temel hedef olarak almıştır ve sadece bölgedeki ya da ülkedeki insanların değil tüm insanların ihtiyaçlarının karşılanmasını hedeflemiştir. Böylece kaynakların kıtlığı devreye girdiğinde, üreticinin önce bölgesindeki kaynakları kullanarak bölgesinin ihtiyacını karşıladığı bir model karşımıza çıkmaktadır (Kala, 2012). Bu durum Elmas Modeli'ndeki talep koşullarını hatırlatmaktadır. Ahi Evran üretim modelinin ortaya çıkış amacının, bölge taleplerini karşılamak olduğu zaten daha önce de bahsedilmiş̧ir. Dolayısıla önce bölge talepleri karşılanarak, halkın ihtiyaçlarının giderildiği, üretim arttı̆̆ında ise dış ticaretin başladığı anlaşılmaktadır.

Ahi Evran'ın üretim modeli ile Porter'ın Elmas Modeli arasındaki uyumu bir tabloda göstermek daha açıklayıcı olacaktır. Bu sebeple çalışmalarımız sonucunda, geçmişteki kümelenmeler ve günümüz kümelenmelerinin özellikleri Porter'ın belirlediği kümelenme boyutları açısından ele alınmış ve Tablo 1'de karşılaş̧tırmalı olarak sunulmuştur:

Tablo 1

Kümelenme örneklerinde bulunan ortak özellikler

\begin{tabular}{|c|c|c|c|c|c|}
\hline \multirow{2}{*}{$\begin{array}{l}\text { ŞEHİR/ } \\
\text { BÖLGE/ } \\
\text { KÜMELENME }\end{array}$} & \multicolumn{5}{|c|}{ FAKTÖR KOŞULLARI } \\
\hline & İnsan Kaynakları & $\begin{array}{l}\text { Fiziksel Altyapı } \\
\text { (Doğal } \\
\text { Kaynaklar) }\end{array}$ & Bilgi Kaynakları & $\begin{array}{l}\text { Sermaye } \\
\text { Kaynakları }\end{array}$ & Altyapı İmkanları \\
\hline $\begin{array}{l}\text { Kaliforniya } \\
\text { Şarap Kümesi }\end{array}$ & $\begin{array}{l}\text { Göçle gelen } \\
\text { yoğun nüfus } \\
\text { (Mueller ve } \\
\text { Sumner, 2005) }\end{array}$ & $\begin{array}{l}\text { Benzersiz doğal } \\
\text { ortam, iklim, } \\
\text { toprak, su } \\
\text { kaynakları } \\
\text { (Mueller ve } \\
\text { Sumner, 2005) }\end{array}$ & $\begin{array}{l}\text { Üniversite, } \\
\text { enstitü, özel } \\
\text { komiteler (Porter, } \\
\text { 1998b) }\end{array}$ & $\begin{array}{l}\text { Üzüm ve şarap } \\
\text { üreticilerinin } \\
\text { kendi sermayeleri } \\
\text { (Mueller ve } \\
\text { Sumner, 2005) }\end{array}$ & $\begin{array}{l}\text { Geniş ve uygun } \\
\text { alanlar, iyi ulaşım } \\
\text { imkanları } \\
\text { (Alcazar, Deseda, } \\
\text { Kelchev ve } \\
\text { Navarro, 2011) }\end{array}$ \\
\hline $\begin{array}{l}\text { Ankara'da Ahilik } \\
\text { Teşkilatı } \\
\text { Kümelenmesi } \\
\text { (Sof Üretimi) }\end{array}$ & $\begin{array}{l}\text { Ticaretle artan } \\
\text { nüfus, canlı bir } \\
\text { şehir (Nurdan, } \\
\text { 2012) }\end{array}$ & $\begin{array}{l}\text { Çevredeki tarım } \\
\text { alanları, iklimi ve } \\
\text { bitki yapısı } \\
\text { (Nurdan, 2012) }\end{array}$ & $\begin{array}{l}\text { Meslek birliği } \\
\text { içerisindeki } \\
\text { ustalar (Ortaylı, } \\
\text { 2010) }\end{array}$ & $\begin{array}{l}\text { Ahilik teşkilatı } \\
\text { üyeleri tarafindan } \\
\text { oluşturulmuş } \\
\text { sermaye }\end{array}$ & $\begin{array}{l}\text { Uygun ulaşım ve } \\
\text { iletişim ağı, } \\
\text { uygun konaklama } \\
\text { imkanları (Taş, } \\
\text { 2014) }\end{array}$ \\
\hline $\begin{array}{l}\text { Eskişehir-Bilecik- } \\
\text { Kütahya Seramik } \\
\text { İş Kümesi }\end{array}$ & $\begin{array}{l}\text { Yeterli düzeyde } \\
\text { insan kaynağı } \\
\text { (Bilim, Sanayi ve } \\
\text { Teknoloji } \\
\text { Bakanlığı, 2012) }\end{array}$ & $\begin{array}{l}\text { Kaliteli ve zengin } \\
\text { hammadde } \\
\text { kaynakları } \\
\text { (Bilim, Sanayi ve } \\
\text { Teknoloji } \\
\text { Bakanlığ } 1,2012 \text { ) }\end{array}$ & $\begin{array}{l}\text { Güçlü bilgi } \\
\text { altyapısına sahip } \\
\text { bilim adamları } \\
\text { (Bilim, Sanayi ve } \\
\text { Teknoloji } \\
\text { Bakanlığı, 2012), } \\
\text { Üniversiteler }\end{array}$ & $\begin{array}{l}\text { Özel sektör ve } \\
\text { ekonomi } \\
\text { bakanlığ1 } \\
\text { (Y1lmaz, 2015) }\end{array}$ & - \\
\hline $\begin{array}{l}\text { OSTİM Savunma } \\
\text { ve Havacıllk } \\
\text { Kümelenmesi }\end{array}$ & $\begin{array}{l}\text { Başkent olması } \\
\text { sebebiyle yeterli } \\
\text { nüfus yoğunluğu } \\
\text { (Oral, 2014) }\end{array}$ & - & $\begin{array}{l}\text { Üniversite, } \\
\text { araştırma } \\
\text { kurumu, } \\
\text { teknopark } \\
\text { (OSTİM } \\
\text { Savunma ve } \\
\text { Havacilık } \\
\text { Kümelenmesi) }\end{array}$ & $\begin{array}{l}\text { Özel sektör ve } \\
\text { ekonomi } \\
\text { bakanlığı (Oral, } \\
\text { 2014; Savunma } \\
\text { Sanayi } \\
\text { Müsteşarlığ1, } \\
\text { 2012) }\end{array}$ & $\begin{array}{l}\text { Başkent olmas1 } \\
\text { sebebiyle } \\
\text { tamamlanmış } \\
\text { altyap1 ve üstyap1 } \\
\text { hizmetleri (Oral, } \\
\text { 2014) }\end{array}$ \\
\hline
\end{tabular}




\begin{tabular}{|c|c|c|c|c|c|}
\hline $\begin{array}{l}\text { Osmanlı } \\
\text { Tersaneleri Ahilik } \\
\text { Teşkilatı } \\
\text { Kümelenmesi }\end{array}$ & $\begin{array}{l}\text { Yeterli düzeyde } \\
\text { insan kaynağ1, } \\
\text { yeni göçler } \\
\text { (Bostan, 2015) }\end{array}$ & $\begin{array}{l}\text { Liman için } \\
\text { elverişli bölgeler }\end{array}$ & $\begin{array}{l}\text { Bölgede yaşayan } \\
\text { yerli halk, denizci } \\
\text { beylikler (Bostan, } \\
2015 \text { ) }\end{array}$ & $\begin{array}{l}\text { Osmanl1 Devleti } \\
\text { (Bostan, 2015) }\end{array}$ & $\begin{array}{l}\text { Aktif ticaret } \\
\text { politikası } \\
\text { sebebiyle iç } \\
\text { bölgelere iyi } \\
\text { düzeyde ulaşım } \\
\text { imkanları } \\
\text { (Köprülü, 2015) }\end{array}$ \\
\hline
\end{tabular}

\begin{tabular}{|c|c|c|c|c|c|}
\hline $\begin{array}{l}\text { ŞEHİR/ } \\
\text { BÖLGE/ } \\
\text { KÜMELENME }\end{array}$ & $\begin{array}{l}\text { Talep } \\
\text { Koşulları }\end{array}$ & $\begin{array}{l}\text { İlgili ve Destekleyici } \\
\text { Endüstriler }\end{array}$ & $\begin{array}{l}\text { Firma Yapis1, } \\
\text { Stratejisi ve } \\
\text { Rekabet }\end{array}$ & Şans Faktörü & $\begin{array}{l}\text { Hükümet } \\
\text { Faktörü }\end{array}$ \\
\hline
\end{tabular}

$\begin{array}{lll} & \text { Önemli yerel } & \text { Tamamlayıcı ve } \\ \text { Kaliforniya } & \text { talep (Mueller } & \text { tedarikçi, çok sayıda } \\ \text { Şarap Kümesi } & \text { ve Sumner, } & \text { endüstri (Porter, } \\ & \text { 2005) } & \text { 1998b) }\end{array}$

$\begin{array}{lll}\begin{array}{l}\text { Bilgi akışı yoğun } \\ \text { bir yapı, güçlü }\end{array} & \text { Altına Hücüm } & \text { Rahat } \\ \text { rekabet (Kunt, } & \text { Dönemi (Mueller } & \text { politikalar } \\ \begin{array}{l}\text { 2010; Porter, } \\ \text { 1998b) }\end{array} & \text { ve Sumner, 2005) } & \text { (Kunt, 2010) }\end{array}$

\begin{tabular}{|c|c|c|c|c|c|}
\hline $\begin{array}{l}\text { Ankara'da Ahilik } \\
\text { Teşkilatı } \\
\text { Kümelenmesi } \\
\text { (Sof Üretimi) }\end{array}$ & $\begin{array}{l}\text { Hükümet, } \\
\text { yerel talep, } \\
\text { küresel talep } \\
\text { (Taş, 2014) }\end{array}$ & $\begin{array}{l}\text { Aynı kumaşı kullanan } \\
\text { ilişkili endüstriler, } \\
\text { hammadde sağlayan } \\
\text { çokça tedarikçi } \\
\text { (Özdemir, 2012) }\end{array}$ & $\begin{array}{l}\text { Ahilik teşkilatı } \\
\text { yönetim yapısı, } \\
\text { bölgesel rekabet } \\
\text { (Kala, 2012) }\end{array}$ & $\begin{array}{l}\text { Ankara'nın } \\
\text { iklimi ve bitki } \\
\text { yapıs1 (Nurdan, } \\
\text { 2012) }\end{array}$ & $\begin{array}{l}\text { Önemli müşter } \\
\text { (Taş, 2014), } \\
\text { denetim rolü } \\
\text { (Özdemir, } \\
\text { 2012) }\end{array}$ \\
\hline
\end{tabular}

\begin{tabular}{|c|c|c|c|c|c|}
\hline $\begin{array}{l}\text { Eskişehir-Bilecik- } \\
\text { Kütahya Seramik } \\
\text { İş Kümesi }\end{array}$ & $\begin{array}{l}\text { Rekabete } \\
\text { yönlendiren } \\
\text { yerel talep ve } \\
\text { küresel talep } \\
\text { (Kaya, 2016) }\end{array}$ & $\begin{array}{l}\text { Aynı hammadde ve } \\
\text { benzer teknolojileri } \\
\text { kullanan ilgili } \\
\text { endüstriler (Bilim, } \\
\text { Sanayi ve Teknoloji } \\
\text { Bakanlığı, 2012) } \\
\text { Hammadde sağlayan } \\
\text { tedarikçiler }\end{array}$ & $\begin{array}{l}\text { Sürekli gelişim ve } \\
\text { inovasyona yönelen } \\
\text { firma yapısı (Bilim, } \\
\text { Sanayi ve Teknoloji } \\
\text { Bakanlığı, 2012) }\end{array}$ & $\begin{array}{l}\text { Kaliteli ve zengin } \\
\text { hammadde } \\
\text { kaynakları } \\
\text { (Bilim, Sanayi ve } \\
\text { Teknoloji } \\
\text { Bakanlığı, 2012) }\end{array}$ & $\begin{array}{l}\text { Bakanlık } \\
\text { destekleri } \\
\text { (Y1lmaz, 2015) } \\
\text { (Bilim, Sanayi } \\
\text { ve Teknoloji } \\
\text { Bakanlığı, } \\
\text { 2012) }\end{array}$ \\
\hline
\end{tabular}

\begin{tabular}{|c|c|c|c|c|c|}
\hline $\begin{array}{ll}\text { OSTİM } & \text { Savunma } \\
\text { ve } & \text { Havac1lık } \\
\text { Kümelenmesi }\end{array}$ & $\begin{array}{l}\text { Hükümet } \\
\text { talebi (Oral, } \\
\text { 2014; Tekeli, } \\
\text { 2010) }\end{array}$ & $\begin{array}{l}\text { Aynı hammadde ve } \\
\text { benzer teknolojileri } \\
\text { kullanan ilgili } \\
\text { endüstriler, } \\
\text { tedarikçiler (OSTİM } \\
\text { Savunma ve Havacılık } \\
\text { Kümelenmesi; Oral, } \\
\text { 2014) }\end{array}$ & $\begin{array}{l}\text { Rekabetçi bir yapı } \\
\text { ve strateji } \\
\text { (OSTİM Savunma } \\
\text { ve Havacıllk } \\
\text { Kümelenmesi) }\end{array}$ & $\begin{array}{l}\text { Başkent olması } \\
\text { ve silah } \\
\text { tezgahlarının } \\
\text { buraya taşınması } \\
\text { (Tekeli, 2010) }\end{array}$ & $\begin{array}{l}\text { Bakanlık } \\
\text { desteği } \\
\text { (Savunma } \\
\text { Sanayi } \\
\text { Müsteşarlığ1, } \\
\text { 2012) }\end{array}$ \\
\hline
\end{tabular}

$\begin{array}{lllll} & & \text { Gemi üretimi için } & \text { Hiyerarşik yönetim } & \text { Sermaye } \\ \text { Osmanlı } & \text { Hükümet } & \text { gerekli tüm } & \text { yapisı, sürekli } & \text { kaynağ1, önemli } \\ \text { Tersaneleri Ahilik } & \text { talebi } & \text { sanatkarlardan oluşan } & \text { gelişime yönelen } & \text { - } \\ \text { Teşkilatı } & \text { (Şenyurt, } & \text { ilişkili endüstriler, } & \text { stratejik yapı, } & \text { müşteri } \\ \text { Kümelenmesi } & \text { 2014) } & \text { hammadde tedarikçisi } & \text { küresel rekabet } & \text { (Bostan, 2015) } \\ & & \text { halk (Bostan, 2003) } & \text { (Bostan, 2015) }\end{array}$

$\mathrm{Bu}$ tablodan da görüleceği üzere, bir kümelenmenin oluşumunu etkileyen ortak özellikler olabilmektedir. Örneğin, Kaliforniya Şarap Kümesi, Ankara'da Ahilik Teşkilatı Kümelenmesi ve Eskişehir-Bilecik-Kütahya Seramik İş Kümesi özellikle birbirlerine benzemektedirler. Hammaddesi doğal kaynaklara bağlı olan bu kümelenmelerde, insan kaynaklarının yeterli düzeyde olduğu hatta göçlerle artarak yoğun bir nüfusa dönüştüğü anlaşılmaktadır. Benzersiz doğal ortamın Kaliforniya Şarap Kümesi'nin oluşumunu etkilediği görülürken, benzersiz iklimin ise sof üretimini etkilediği, keçilerin Ankara'nın ikliminden kaynaklı olarak, tiftiklerinin benzersiz bir hal aldığı bilinmektedir. Eskişehir-Bilecik-Kütahya Seramik İş Kümesi'nin oluşumunu ise o bölgelerde yıllardır bulunan kaliteli ve zengin hammadde kaynağı olan toprağın etkilediği açıktır. Bilgi kaynağı olarak hem Kaliforniya Şarap Kümesi'nde hem de Eskişehir-Bilecik-Kütahya Seramik İş Kümesi'nde 
üniversitelerin bulunduğu anlaşılmaktadır. Nitekim ahilik teşkilatı eğitim faaliyetlerini kendi bünyesinde karşıladığından, meslek birliği içerisindeki ustaların bilgi kaynağını oluşturduğu görülmektedir. Kaliforniya Şarap Kümesi'nin sermaye kaynaklarını, geçmiş dönemlerde ahilik teşkilatında da olduğu gibi üreticilerin kendi sermayelerinin oluşturuyor olması ise dikkat çeken diğer bir husustur. Tüm kümelenmelerde ulaşım imkanlarının yeterli veya iyi düzeyde olması, her birinde yerel talep veya hükümet talebinin mutlaka olması ve neredeyse tüm kümelenmelerde aynı hammadde ve teknolojileri kullanan ilgili endüstriler bulunması da dikkat çekmektedir.

OSTIM Savunma ve Havacılık Kümelenmesi ile Osmanlı Tersaneleri Ahilik Teşkilatı Kümelenmesi'nin en önemli ortak noktası ise hükümet talebidir. Bu kümelenmelerin gelişiminde hükümetin savunma ihtiyaçları öncelikli olmuştur. Kurtuluş Savaşı'nda Ankara savunma sanayisinin merkezi haline gelmiş, sonrasında Eskişehir'deki silah tezgahları Ankara'ya taşınmış ve sonrasında Ankara siyasal karar merkezi olmuştur. Ankara'nın başkent olmasıyla birlikte, devlet kurumlarının idari binalarının yapımı, inşaat malzemeleriyle ilgili imalathanelerin kurulmaya başlamasını tetiklemiştir (Oral, 2014). Böylece savunma sanayisi gelişerek kümelenme halini almıştır. Osmanlı Tersanelerinde ahilik teşkilatı kümelenmesinin oluşumunun da hükümetin savaşlar sebebiyle savunma ve donanma ihtiyaçlarından kaynaklandığı açıktır. Yerli halkın teknik bilgilerini Osmanlı donanmasına aktarması (Bostan, 2015), hali hazırda ticaret sebebiyle gelişmiş olan ulaşım ve konaklama imkânları Osmanlı Tersanelerinin de gelişimini tetiklemiş olan özelliklerdendir.

\section{Kümelenme Özelliklerinde Ahilik Teşkilatı}

Bu bölümde ilk olarak Porter'ın küme tanımını ele almak gerekmektedir. Porter'a göre kümeler, birbiriyle bağlantılı olan işletmeler ve kurumların belirli yerlerde coğrafik olarak yoğunlaşmalarıdır (Porter, 1998b). Bu konuyla ilgili olarak ahilik teşkilatı incelendiğinde, şehirlerin merkezinde ahilik teşkilatının binası olarak bedestenlerin yer aldığını, etrafında ise diğer esnaf ve sanatkârların çarşılarının kurulduğunu, merkeze bağlanan sokakların neredeyse tümünde her dalda faaliyet gösteren esnaf ve sanatkârların olduğunu görmekteyiz. Bu sokaklarda aynı meslekle uğraşanların, dolayısıyla aynı işletmelerin yoğunlaştı̆̆ı anlaşılmaktadır.

Porter kümelerin, birbiriyle bağlantılı endüstrilerin, uzmanlaşmış tedarikçilerin ve uzmanlaşmış altyapı sağlayıcılarının tamamını kapsadığını belirtmektedir (Porter, 1998b). Ahilik teşkilatı da genel olarak, hammaddeyi etraftan, özellikle şehre özgü hammaddeler ve şehrin yakın çevresindeki hammaddelerden tedarik eden, bunları işleyecek araç ve personeli bünyesinde barındıran ve ürettiğini satan bir sistem olmuştur. Şehre özgün hammaddelerin o şehirde veya yakın çevresinde oluşu, belirli tarz işçilik tekniğinin de uzun zamandır bir gelenek halinde o şehirde toplanmasını sağladığından, uzmanlaşmış tedarikçiler ile uzmanlaşmış işgücünün bu şekilde ahilik teşkilatında mevcut olduğu anlaşılmaktadır. Aynı zamanda ahilik teşkilatında uzmanlaşmanın, yani bir kişinin sadece bir sanat veya meslekle uğraşmasının kural olarak yer aldığı, kurala uymayanların teşkilattan çıkarıldığı bilinmektedir. Son olarak ahilik teşkilatının da kümeler gibi, birbiriyle bağlantılı endüstrileri kapsadığı gayet açıktır. Bu durum bizzat teşkilatın kurucusu Ahi Evran'ın sözleriyle kanıtlanabilmektedir: “...demircilik, marangozluk gibi çeşitli meslekleri yürütmek için çok insan gerekli olduğu gibi, demircilik ve marangozluk da bir takım alet ve edevatla yapılabileceği için bu alet ve edevatı tedarik için de çok sayıda insana ihtiyaç vardır...."

Son olarak Porter kümelerin çoğunun, kamu kurumları ve üniversiteler, standardizasyon kurumları, mesleki eğitim kurumları ve sendikalar gibi uzmanlaşmış eğitim, öğretim, araştırma, bilgi ve teknik destek sağlayan diğer kurumları da kapsadığını belirtmiştir (Porter, 1998b). Ahilik teşkilatının kusursuz bir hiyerarşi ile işlediği, bir sorun çıktığında kendi içinde çözdüğü, devlet ile esnaf arasındaki ilişkileri düzenlediği ve aynı zamanda, ücretlerin, ürün çeşitlerinin ve fiyatların ahilik teşkilatı tarafından belirlendiği bilinmektedir. Dolayısıyla ahilik teşkilatının bir kamu kurumu gibi görev yaptığı en başta söylenebilecektir. Yine ahilik teşkilatının asli görevleri olduğu bilinen, ürün ve kalite kontrolü ile fiyat tespiti konuları ele alındığında ahilik teşkilatının kendi içinde standardizasyon kurumu görevini yürüttüğü de görülmektedir. Her ahinin belirli kalite ve miktarlarda hammadde kullandığ1, belirli üretim tekniklerine bağlı kaldığ 1 ve ürettiği eşyayı belirli bir fiyata sattı̆̆ı; bu 
hususlarda farklı uygulamalar gerçekleştirenlerin cezalandırıldığ 1 yadsınmaz bir gerçekliktir. Dolayısıyla denetimi sağlayan kamu kurumu gibi görev yaptığı da söylenebilecektir. Nitekim ahilik teşkilatının aynı zamanda bir eğitim kurumu görevi üstlendiği de bilinmektedir. Hem mesleki eğitim hem ahlaki eğitim ahilik teşkilatı aracılığıyla verilmiş, döneminin eğitim kurumu vazifesini de ahilik teşkilatı üstlenmiştir. Etkili mesleki eğitimin sağlanması usta-çırak ilişkisi sayesinde gerçekleşmiştir. Ahlaki eğitim ise zaviyelerde verilmiştir. Sonuç olarak ahilik teşkilatının üniversite gibi bir kurumu bünyesinde barındırdığı, bilgi ve teknik destek sağlayan bir yapısının olduğu açıkça anlaşılmakta, kümelenme tanımı içerisindeki özelliklerle uyumlu olduğu görülmektedir. Hatta kendi bünyesinde sağladığı özellikler düşünüldüğünde ahilik teşkilatının yeterince kapsamlı bir yapı olduğuna kanaat getirilmektedir.

Morosini'nin endüstriyel kümelerle ilgili yapmış olduğu tanımda kümelenmelerin sosyoekonomik bir varlık olduğuna vurgu yapılmıştır (Morosini, 2004). Ahilik kavramının tanımı yapılırken, insanı her şeyden üstün tutmayı ve içinde bulunduğu dönemin toplumsal ihtiyaçlarını karşılamayı amaç edinmiş; hem toplumsal, kültürel, eğitsel ve dini; hem de ekonomik, sınai ve ticari faaliyetlerde bulunmuş olan bir teşkilatı tanımladığı göz önüne alınmalıdır. Bu tanım göz önüne alındığında ahilik teşkilatının sosyo-ekonomik bir varlık olduğu rahatlıkla söylenebilmektedir.

Ahilik teşkilatı üyeleri arasında fütüvvet teşkilatının moral ve etik kurallarının benimsenmiş olması, "biz" duygusunu ortaya çıkaran "sosyal sermaye" ye de atıf yapabilmektedir. Sosyal sermaye, kişisel görüşmeler yoluyla işlem maliyetinin düşmesini, daha az bürokratik prosedürler izlenmesini, kişisel ve yerel bilgi akışı yoluyla düşük maliyetle bilgi elde edilmesini ve doğrudan temaslar yoluyla daha iyi işbirliği ve aralarında güvene dayalı ilişkiler kurulmasını sağlamaktadır (İmer, 2015). Tüm bu özelliklerin, kurulduğu dönemin şartlarına da bağlı olarak ahilik teşkilatında yer aldığı rahatlıkla söylenebilecektir. Özellikle teşkilattaki, yamak-çırak-kalfa-usta hiyerarşisi ve bu hiyerarşi içindekilerin baba-evlat ilişkisiyle birbirine bağlanmasının, güvene dayalı ilişkiler kurulmasını hızlandırdığı bir gerçektir.

Küme kavramına en yakın kavramın düşünsel öncülüğünü yapan Marshall'ın da bir alanda faaliyet gösteren işletmelerin neden birbirine daha yakın yerleşerek daha verimli olduklarına ilişskin belirlediği üç sebep bulunmaktadır. Bu sebepler, işgücü havuzu, ihtisaslaşmış tedarikçiler ve bilginin yayılmasıdır (Alsaç, 2010). Ahilik teşkilatında her meslek dalının bir sokakta yer aldığı bilindiğine göre bu sokaklarda işgücü havuzu bulunacağ 1 ve bilginin rahatlıkla yayılacağı açıktır. Ahilik teşkilatında hammadde alımı tek elden yapıldığından, buna bağlı olarak ihtisaslaşmış tedarikçilerin olduğu da anlaşılmaktadır.

Kümelerin, merkez ve tamamlayıcı özel sektörü ile bilgi ve işbirliği kurumları arasında sinerjik ve birbirini besleyen bir ilişki olması; eğitim kurumları, kamu kurumları, yerel yönetimler, odalar ve diğer işbirliği kurumlarının, özel sektöre katkı sağlayarak bölge ekonomisinin gelişmesine ve böylece bölgesel kalkınmaya destek vermesi gerekmektedir (Türkiye Cumhuriyeti Ekonomi Bakanlığı, t.y.). Ahilik teşkilatının genel çatısı altında da böyle bir ilişki kurulduğu, bölgesel ve ulusal koordinasyonun sağlandığ 1 görülmektedir. Ahilik teşkilatı, Anadolu'nun her şehrinde ihtiyaca yönelik ve hammadde kaynaklarına bağlı olarak kurulmuş olmakla birlikte, tüm şehir teşkilatlarının ise bir merkezden yönetildiği bilinmektedir. Bu durum ulusal anlamda sinerjik bir yapının oluşturulduğunu kanıtlamaktadır. Aynı zamanda sanayi öncesi ekonomide kaynakların mümkün olduğunca eşit dağıtıldığı, iktisadi yapıya küçük ölçekli birimlerin hâkim olduğu bilinmektedir. Bu şartlar altında üretimin devam edebilmesi için gerekli yatırımları yapabilecek imkanlar bulunmamıştır. Ahilik teşkilatının da önemli fiziki yatııım gerektiren, çarşı, bedesten, kervansaray gibi tesisleri ve boyahane, debbağhane gibi imalathaneleri kendi imkanları ile yapmaları mümkün olmamıştır. Bu durumda önce Selçuklular, sonra Osmanlılar olmak üzere kamu kurumları ve yerel yönetimler ahilik teşkilatına katkı sağlamıştır. Selçuklular vakıf iktisadi işletmelerini ortaya çıkarmış, Osmanlılar bu kurumları geliştirmiştir. Vakıf iktisadi işletmeleri ahilik teşkilatına sermaye desteği sağlayarak, ekonominin gelişimini de destekleyen en önemli yapılar olmuştur. 
Yapılan bir araştırmaya göre küme geliştirmenin ön koşulları arasında kalifiye işçilik ile geleneksel ve tarihi ön koşullar olduğu görülmektedir (Ahiler Kalkınma Ajansı, t.y.). Nitekim ahilik teşkilatında bir yamağın usta olabilmesi için 8 yıllık bir eğitimden geçmesi gerektiği ve aynı zamanda bazı sınavlardan başarılı olması, ahlaki anlamda da yeterli olması gerektiği göz önüne alındığında kalifiye işçiliğin ahilik teşkilatında da önemli yeri olduğu anlaşılmaktadır. Ahilik teşkilatında bölgelerde oluşan meslek dallarının, özellikle bölgelerde çok bulunan hammadde kaynaklarına bağlı olarak şekillendiği göz önüne alındığında; o bölgedeki yerel halkın o meslekle ilgili teknik bilgi ve becerilerinin bulunacağı, kendilerinden sonra gelen toplumlara bu bilgileri aktaracağı düşünülmelidir. Geleneksel ve tarihi ön koşullar bu şekilde oluşmaktadır.

Kümelenmeler, bir milletin kendi kendine yetmesi isteğinden de ortaya çıkabilmektedir (Mercan vd., 2004). Ahi Evran da sadece yeterli üretimi sağlamanın ekonomiyi geliştireceğini düşünmemiş, yapılan üretimle toplumun ihtiyaçlarını karşılamayı da hedeflemiştir. Ahi Evran'ın bu düşüncesi ile ihtiyaçların karşılanarak toplum refahının arttırıldığı, böylece öncelikle bir milletin kendi kendine yetebilmesinin sağlandığı görülmektedir.

Kümelenmelerin önemi pazarlama noktasında da ortaya çıkabilmektedir. Bir kümelenme, genellikle belirli bir alanda belirli bir yerin ününün artmasını sağlamaktadır (Porter, 1998b). Bu durumu günümüzde görebileceğimiz gibi ahilik teşkilatında da rahatlıkla görebilmekteyiz. Buna örnekler, Konya'da kamerüddin adı verilen kayısının meşhur olması, Aksaray'da koyun yününden dokunan halıların meşhur olması, Ankara'nın sof ile meşhur olması şeklinde verilebilmektedir.

Son olarak, kümelenmelerin belirli bir yaşam döngüsüne sahip oldukları belirtilmektedir. Buna göre embriyonik aşamadaki bir kümelenme, yenilik ve icat kaynaklarına veya mevcut ve gittikçe genişleyen endüstri liderlerine bağlıdır. Pazar genişledikçe kümelenme, girişimci ve rekabetçileri cezbetmekte, böylece büyüme aşamasına geçmektedir (Rosenfeld, 2003). Ancak tarihsel farklı1ıktan dolayı bu özelliğin ahilik teşkilatında bulunduğu söylenemeyecektir. Nitekim ahilik teşkilatının kurulmuş olduğu dönemlerde nüfus seviyesi daha düşük, iletişim imkânları oldukça zayıftır. Endüstriyel gelişmeler o dönemde daha durağan seyretmektedir.

Tarihsel farklılıktan kaynaklanan durum haricinde ahilik teşkilatının belirgin kümelenme özellikleriyle temel olarak örtüştüğü karşılaştırmalar sonucunda açıkça anlaşılmaktadır.

\section{Sonuç}

Sonuç olarak ahilik teşkilatının belirli özelliklerinin kümelenme özelliklerini yansıttığı, kümelenme özelliklerinin her biri ile ahilik teşkilatında yer alan özelliklerin eşleştirilebildiği görülmektedir. Buna göre ahilik teşkilatının, kümelenme özelliklerini taşıdığı ve bölgesel bir kümelenme modeli olduğu söylenebilmektedir. Kümelenme özelliklerinden coğrafik yoğunlaşmanın, ahilik teşkilatının da en belirgin özelliği olduğu görülmektedir. Birbiriyle ilişkili ve tedarikçi endüstriler, ahilik teşkilatı içerisinde yer almış her biri ayrı meslek birlikleri olarak teşkilatlanmıştır.

Uzmanlaşma, ahilik teşkilatının önemli kurallarından birisi olarak var olmuş, dolayısıyla ahilik teşkilatında uzmanlaşmış tedarikçiler ve uzmanlaşmış işgücünün varlığ tartışılmaz bir gerçeklik olmuştur. Kümeler bünyelerinde üniversiteler, standardizasyon kurumları, mesleki eğitim kurumları gibi bilgi ve teknik destek sağlayan kurumları barındırmaktadır. Nitekim ahilik teşkilatının da hem ahlaki hem mesleki eğitim veren bir kuruluş olarak üniversitelerin sağladığı bilgi desteğini sağladığı görülmektedir. Aynı zamanda ahlaki eğitim boyutuyla ahilik teşkilatının günümüz kümelenmelerinden bir adım önde olduğu, günümüze güzel bir örnek teşkil edebileceği söylenebilmektedir. Çoban (2018) da değerler eğitimi ve ahilik ilkelerini birlikte ele aldığı makalesinde; ahiliğin bizim dünyaya bakışımızda ve problemlerimizin çözümünde insan ve ahlak temelli alternatifler sunması açısından önemli bir sosyal kurum olduğunu, ahiliği daha iyi anlamamız gerektiğini, her türlü pragmatist düşünceden arınarak insana hizmeti önceleyen ahiliğin, arkasında yüzlerce yıl örnek alınacak bir model miras bıraktığını belirterek bizim bu düşüncemizi pekiştirmektedir. 
Bu çalışma ile ortaya çıkan diğer bir husus, diğer birçok bilim dalında olduğu gibi, kümelenme alanında da ortaya konulan bakış açılarının Batı merkezli olduğudur. Bir diğer ifadeyle, işletmecilik ve yönetim alanındaki kavramlar Batı'daki gelişim seyrine göre oluşturulmaktadır (Aydoğan ve Delibaş, 2017). Ahilik teşkilatının, tarihi açıdan da bakıldığında esasında kümelenme kavramının temelini oluşturduğu görülmektedir. Bu noktada, bu çalışma ile eski yazılı eserlerden ekonomik ve ticari konuları içeren eserlerin ve bir yönüyle Türk işletmecilik tarihine katkı sağlayacak olan eserlerin tespit edilerek Türkçe'ye çevirilmesinin gerekliliği su yüzüne çıkmaktadır. Bu çalışmanın sınırlılı̆̆ı, eski yazılı eserlerin okunamamış olması sebebiyle verilerin ikincil kaynaklardan toplanmış olmasıdır. Sonraki çalışmalarda, eski yazılı eserlerden ekonomik ve ticari konuları içerenlerin Türkçe'ye çevrilerek birincil kaynaklardan verilerin toplanması, Türk işletmecilik tarihi yazınına katkı sağlayacaktır.

Bu çalışma, tarihsel süreçte farklı coğrafyalardaki ekonomik birlikleri ele alarak karşılaştırmalı bir çalışma yapmış olması sebebiyle literatürdeki boşluğu doldurmaktadır. Bu açıdan önemli olduğu düşünülmekle birlikte, ülkemizde kümelenme yapısı oluşturulabilecek bölgelere, ahilik teşkilatı bölgesel kümelenme modelinin ahlaki yönü de yadsınmadan, iyi bir örnek teşkil edebileceği önerilmektedir.

Açıklama: Bu makale, Gazi Üniversitesi Sosyal Bilimler Enstitüsü İşletme Anabilim Dalında hazırlanan "Türk işletmecilik tarihinde kümelenme modeli olarak ahilik teşkilatı" isimli yüksek lisans tezinden türetilmiştir.

\section{Kaynaklar}

Ahiler Kalkınma Ajans1. (t.y.). Yerel Ekonomik Kalkınma ve Kümelenme Rehberi. http://ahika.gov.tr/assets/ilgilidosyalar/Kumelenme-Rehberi.pdf $\quad$ adresinden $\quad 02.12 .2016$ tarihinde erişilmiştir.

Akdăg, M. (2014). Türkiye’nin iktisadi ve içtimai tarihi (2. Baskı). İstanbul: Yapı Kredi.

Akdağ, R., Mete, M. ve Emhan, A. (2014). Diyarbakır tekstil ve hazır giyim sektörünün elmas modeli ile kümelenme analizi. Süleyman Demirel Üniversitesi İktisadi ve İdari Bilimler Fakültesi Dergisi, 19(2), 323-431.

Alcazar, J.C., Deseda, C.A., Kelchev, A. and Navarro, F. (2011). Internet based services cluster in Silicon Valley, Microeconomics of Competitiveness Final Report, Harvard Business School, Boston.

Alsaç, F. (2010). Bölgesel gelişme aracı olarak kümelenme yaklaşımı ve Türkiye için kümelenme destek modeli önerisi. Planlama Uzmanlığı Tezi, Devlet Planlama Teşkilatı Müsteşarlığı, Ankara.

Aslan, E. (2014). Ahi örgütlerinden Urfa sira gecesine uzanan bir kültür geleneği. Ahi Evran Üniversitesi Sosyal Bilimler Enstitüsü Dergisi, 1(1), 5-15.

Aydoğan, E. ve Delibaş, M. B. (2017). Ahilik kurumu ve örgütsel vatandaşlık davranış1. Üçüncü Sektör Sosyal Ekonomi, 52(1), 1-18.

Aziz, K. and Norhashim, M. (2008). Cluster-based policy making: Assessing performance and sustaining competitiveness. Review of Policy Research, 25(4), 349-375.

Bayram, M. (1991). Ahi Evran ve Ahi Teşkilatının kuruluşu. Konya: Damla. 
Bilim, Sanayi ve Teknoloji Bakanlığı. (2012). Türkiye seramik sektörü strateji belgesi ve eylem planı (2012-2016). Ankara: Sanayi Genel Müdürlüğü.

Bostan, İ. (2003). Osmanlı Bahriye Teşkilatı: XVII. Yüzyılda Tersane-i Amire (2. Bask1). Ankara: Türk Tarih Kurumu.

Bostan, İ. (2015). Beylikten imparatorluğa Osmanlı denizciliği (7. Bask1). İstanbul: Kitap.

Bulut, M. (2014). Osmanlı dünyasında vakıflar ve finans. İçinde Kurtoğlu, M. (Ed.), Vakıf ve iktisat sempozyum (ss. 33-35). Ankara: Vakıflar Genel Müdürlüğü.

Celil, F. (2011). Ahilik Tarikatının Azerbaycan'da izleri. İçinde Güleç, E., Köksal, F., Işıksalan, S.N. ve Gündüz, A. (Ed.), 1. Uluslararası ahilik kültürü ve Kırşehir sempozyumu, I (ss. 233-239). Kırşehir: SFN.

Çağatay, N. (1988). Anadolu Türklerinin ekonomik yaşamları üzerine gözlemler (Bu alanda ahiliğin etkileri). Belleten, LII(203), 485-500.

Çağatay, N. (1989). Bir Türk kurumu olan ahilik. Ankara: Türk Tarih Kurumu.

Çoban, M. (2018). Değerler eğitimi ve ahilik ilkeleri. Ahi Evran Üniversitesi Sosyal Bilimler Enstitüsü Dergisi, 4(1), 87-102. doi: 10.31592/aeusbed.337602

Doğru, H. (1991). XVI. yüzyllda Sultanönü sancağında ahiler ve ahi zaviyeleri. Ankara: T.C. Kültür Bakanlığı.

Eraslan, İ. H. ve Güngören, M. (2013). Endüstriyel kümelenmelerin iktisadi tarihi ve gelişim süreci. Elektronik Sosyal Bilimler Dergisi, 12(45), 171-197.

Gülerman, A. ve Taştekil, S. (1993). Ahi teşkilatının Türk toplumunun sosyal ve ekonomik yapısı üzerindeki etkileri. Ankara: T.C. Kültür Bakanlığı.

Güllülü, S. (1977). Sosyoloji açısından ahi birlikleri. İstanbul: Ötüken.

İmer, H. (2015). Türkiye imalat sanayiinde sektörel kümelenme ve rekabet gücü: Seçilmiş bölgeler için bir analiz. Doktora Tezi, Dokuz Eylül Üniversitesi Sosyal Bilimler Enstitüsü, İzmir.

John, C. H. and Pouder, R. W. (2006). Technology clusters versus industry clusters: Resources, networks, and regional advantages. Growth and Change, 37(2), 141-171.

Kala, A. (2012). Debbağllktan dericiliğe: İstanbul merkezli deri sektörünün doğuşu ve gelişsimi. İstanbul: Zeytinburnu Belediyesi Kültür.

Kaya, D.S. (2016). Seramik sektörü.

https://ekonomi.isbank.com.tr/ContentManagement/Documents/sr201607_seramiksektoru.pdf adresinden 09.12.2016 tarihinde erişilmiştir.

Kazıc1, Z. (1988). Ahilik. İçinde TDV İslam Ansiklopedisi (Cilt. 1, 540-542). https://islamansiklopedisi.org.tr/ahilik adresinden 10.11.2016 tarihinde erişilmiştir.

Köksal, M. F., Kurtoğlu, O., Karaköse, H. ve Şenödeyici, Ö. (2008). Kırşehir Müzesi’ndeki ahilik belgeleri: Ahi şecerenameleri, beratlar, vakfiyeler. Kırşehir: Kırşehir Valiliği.

Köprülü, M. F. (2015). Osmanlı İmparatorluğunun kuruluşu. İstanbul: Alfa. 
Kunt, İ. V. (2010). Kobi'lerin rekabetçi avantaj sağlamalarında kümelenme stratejisinin rolü ve bir uygulama.Yüksek Lisans Tezi, Dokuz Eylül Üniversitesi Sosyal Bilimler Enstitüsü, İzmir.

Küçükdağ, Y. (2016). Ahilik (Osmanlı dönemi). İçinde Ahilik Ansiklopedisi (2. Bask1, Cilt I, 223227). Ankara: CTA.

Mercan, B., Halıc1, N. S. ve Baltacı, N. (2004, Kasım). Küresel ve bölgesel rekabet avantajı sağlayıcısı olarak sanayi odaklarının (clusters) oluşumu ve gelişimi. 3. Ulusal Bilgi Ekonomi ve Yönetim Kongresi’nde sunulan bildiri, Eskişehir.

Morosini, P. (2004). Industrial clusters, knowledge integration and performance. World Development, 32(2), 305-326.

Mueller, R.A.E. and Sumner, D. A. (2005, July). Clusters of grapes and wine. Annual Meeting of the American Agricultural Economics Association, Providence. http://www.unikiel.de/Agraroekonomie/Abteilungen/II/PDFs/wineclustersaaea.pdf adresinden 13.12.2016 tarihinde erişilmiştir.

Nurdan, S. (2012). Osmanlının son döneminde Ankara tiftik keçisinin yok oluşuna karşı Beypazarı'nda yapılan bazı mücadeleler. İçinde Kurt, Y. ve Ünlü, E. (Ed.), Tarihte Ankara Uluslararası Sempozyumu Bildiriler (ss. 749-759). Ankara: A.Ü. DTCF.

Odabaş1, Z. (2008). Bir ahi dostu: Franz Taeschner hayatı ve eserleri. Ankara: A.E.Ü. Ahilik Kültürünü Araştırma Merkezi.

Oral, M. (2014). Kümelenme yaklaşımının firma performansına etkisi: Ankara OSTiMM örneği. Yüksek Lisans Tezi, Ankara Üniversitesi Sosyal Bilimler Enstitüsü, Ankara.

Ortaylı, İ. (2010). Türkiye teşkilat ve idare tarihi. Ankara: Cedit Neşriyat.

OSTIM Savunma ve Havacilı Kümelenmesi. Küme hakkında. http://www.ostimsavunma.org/tr/content/kume-hakkinda/281 adresinden 10.12.2016 tarihinde erişilmiştir.

Özdemir, R. (2012). Ankara'da sof ve şal üretimi (1770-1850). İçinde Kurt, Y. ve Ünlü, E. (Ed.), Tarihte Ankara Uluslararası Sempozyumu Bildiriler (ss. 729-735). Ankara: A.Ü. DTCF.

Porter, M. E. (1990a). The competitive advantage of nations. Harvard Business Review, 73-91.

Porter, M. E. (1990b). The competitive advantage of nations. London: The Macmillan.

Porter, M. E. (1998a, September). The Adam Smith address: Location, clusters, and the "new" microeconomics of competition. 39th Annual Meeting of National Association for Business Economics, New Orleans.

Porter, M. E. (1998b). Clusters and the new economics of competition. Harvard Business Review, $77-$ 90.

Porter, M. E. (2000). Location, competition, and economic development: Local clusters in a global economy. Economic Development Quarterly, 14(1), 15-34.

Rosenfeld, S. A. (2003). Expanding opportunities: Cluster strategies that reach more people and more places. 1. European Planning Studies, 11(4), 359-377.

Savunma Sanayi Müsteşarlığı. (2012). Savunma Sanayi Gündemi Dergisi, 2(19). Ankara: Art. 
Soykut, R. H. (1980). Insanlık bilimi ahilik. Ankara: Halk Bankası.

Şeker, M. (2001). İbn Batuta'ya göre Anadolu'nun sosyal-kültürel ve iktisadi hayatı ile ahilik. Ankara: T.C. Kültür Bakanlığı.

Şenyurt, A. (2014). Osmanlı tersanelerinin gelişiminde Ahi Evren'in ahi kümelenme modeli. Tarih ve Uygarlik Istanbul Dergisi, 5, 181-198.

Şimşek, M. (2002). Ahilik: TKY ve tarihteki bir uygulaması. İstanbul: Hayat.

Taş, H. (2014). Ankara'nın bütüncül tarihine katkl: XVII. yüzyılda Ankara (2. Baskı). Ankara: Türk Tarih Kurumu.

Türkiye Cumhuriyeti Ekonomi Bakanlığı. (t.y.). Yerel Paydaşlar İçin Kümelenme Kılavuzu. http://www.smenetworking.gov.tr/userfiles/pdf/belgeler/ekonomiBakanligi/1_yerel_paydaslar. pdf adresinden 04.12.2016 tarihinde erişilmiştir.

Turan, K. (1996). Ahilikten günümüze mesleki ve teknik eğitimin tarihi gelişimi. İstanbul: M. Ü. İlahiyat Fakültesi Vakfi.

Yıldız, S. ve Alp, S. (2014). Bir kümelenme örneği olarak Kars kaşar peyniri endüstri kümesi. H.Ü. İktisadi ve İdari Bilimler Fakültesi Dergisi, 32(1), 249-272.

Yılmaz, C. (2015). Onuncu kalkınma planı (2014-2018) seramik çalışma grubu raporu. Ankara: Kalkınma Bakanlığı. 


\section{Extended Abstract}

\section{Introduction}

Akhism, which emerged as a religious and social structure in Anatolia in the thirteenth century, has become an organization of tradesmen and craftsmen in time and has survived until the eighteenth century. With the centralization of the Ottoman State, it continued its activities as an organization representing the tradesmen only. The organization of tradesmen is a system that collects raw materials, hosts tools and personnel to process them and sells what they produce. The organization of Akhism, which was the tradesmens' organization of the Ottoman Empire, lived as the basic institution of the Ottoman production system.

It has seen that Akhism is an example to clusters with some features. Clusters are geographical concentration of interconnected enterprises and institutions in certain places. These concentrations generally occur in places where there is abundant raw material, large market or high demand. It has understood that these characteristics also play a role in the formation of the organization of Akhism.

When the literature examined, it has seen in previous studies, Akhism was considered as a cluster model, but there was no explanation in the theoretical framework. Therefore, in this article, it is examined in the light of the data collected by written document analysis, that Akhism is a regional cluster example. Since the data collected about Akhism and clusters, provides the opportunity to compare, it is aimed to make a comparative analysis.

\section{Method}

In this study, qualitative research method was used. The data were collected by written document analysis, which is one of the qualitative data collection methods. The features of cluster concept are discussed. In this context, the organization of Akhism, which was formed in previous societies and has cluster characteristics, was examined, similarities were determined and at the same time compared with the clusters formed by today's societies. So, the organization of Akhism, which is a sociological formation, was tried to be examined within the theoretical framework.

The features of clusters included in Akhism were first handled in terms of the cluster elements set by Porter. Later, the definitions of clusters were handled and the properties mentioned in the definitions were searched in Akhism. These comparisons are transferred to a table through examples. As it can be seen in the table that the examples are given together, the clusters formed both in the past and today show similar features and showed the correctness of the path followed in this study.

\section{Result}

When comparing according to Porter's cluster definition, the following results are obtained:

According to Porter, clusters are the geographical concentration of interconnected businesses and institutions in certain places. In this context, when Akhism is analyzed, we see that there are bedestens as the building of the organization of Akhism in the center of the cities, and the bazaars of tradesmen and craftsmen have been established around it and there are tradesmen and craftsmen operating in every branch in almost all of the streets connected to this center.

Porter states that clusters cover all interconnected industries, specialized suppliers and specialized infrastructure providers. It is clear that Akhism encompasses interconnected industries, such as clusters. This can be proven by the words of Ahi Evran, the founder of the organization itself: "... as many people are required to carry out various professions such as blacksmithing, carpentry, as well as these professions can be done with a set of tools and equipments, a large number of people are also needed to supply this tools and equipments." At the same time, it is understood that the 
organization of Akhism is a system that collects raw materials, especially city-specific raw materials around the region, and includes the tools and personnel to process them, so that specialized suppliers and specialized workforce are present in the organization of Akhism.

Finally, Porter stated that most of the clusters include specialized education, teaching, research and the other institutions providing information and technical support like unions, public institutions, universities, standardization institutions. It is known that the organization of Akhism operates with a flawless hierarchy, resolves the problems in itself, regulates the relations between the state and the tradesmen, and at the same time, wages, product types and prices are determined by Akhism. Therefore, it can be said that the organization of Akhism functions like a public institution. When the issues of product and quality control and price determination, which are known to be the primary duties of the organization of Akhism, are considered, it is also seen that Akhism carries out the task of standardization in itself. As a matter of fact, it is known that the organization of Akhism also acts as an educational institution. Both vocational education and moral education were provided through the organization of Akhism, and so undertaken the duty of the educational institution of its period. As a result, it is clearly understood that Akhism has a structure that provides information and technical support, and it is seen that it is compatible with the characteristics within the cluster definition.

\section{Discussion and Conclusion}

As a result, it is seen that certain characteristics of the organization of Akhism reflect the cluster characteristics. Accordingly, it can be said that Akhism has cluster features and is a regional cluster model. It has seen that geographical concentration, which is one of the cluster characteristics, is the most prominent feature of the organization of Akhism as well. As a corporation that provides both moral and vocational education, Akhism provided information support such as universities. At the same time, it can be said that, with the moral education dimension, the organization of Akhism is one step ahead of today's clusters and can serve as a good example for the present day. This study is thought to be important in terms of filling the gap in the literature. Also as a regional clustering model of the organization of Akhism suggested to be an example for the regions where cluster structure can be established in our country. 